\title{
PEMBENTUKAN INDEKS KEMISKINAN MULTIDIMENSI ANAK DAN PEMANFAATANNYA UNTUK PENGENTASAN KEMISKINAN BERKELANJUTAN DI INDONESIA TAHUN 2017
}

\author{
(The Construction of Child Multidimensional Poverty Index and Its Utilization for Sustainable \\ Poverty Alleviation in Indonesia in 2017) \\ Lalu Ardani Aulia1, Ika Yuni Wulansari² \\ Politeknik Statistika STIS ${ }^{1,2}$ \\ Politeknik Statistika STIS, Jalan Otto Iskandardinata Raya No. 64 C, Jatinegara, Jakarta Timur, 13330 \\ E-mail: 15.8704@stis.ac.id
}

\begin{abstract}
ABSTRAK
Pengukuran kemiskinan yang hanya melihat aspek moneter sudah sejak lama mendapat kritik. Kemiskinan merupakan fenomena multidimensi, sehingga pengukurannya seharusnya dilakukan secara multidimensi, terutama kemiskinan anak. Ukuran kemsikinan anak di Indonesia selama ini masih diturunkan dari ukuran kemiskinan rumah tangga tempat anak tersebut tinggal. Dalam kenyataannya, kebutuhan anak-anak berbeda dengan orang dewasa dan distribusi pendapatan di dalam rumah tangga tidak selalu merata. Penelitian ini dilakukan untuk mengukur kemiskinan anak di Indonesia secara multidimensi melalui pembentukan Indeks Kemiskinan Multidimensi (IKM) Anak berdasarkan metode Alkire-Foster. Indeks tersebut diharapkan dapat dimanfaatkan oleh pembuat kebijakan dalam upaya pengentasan kemiskinan anak sehingga potensi mereka dapat dikembangkan secara maksimal agar mampu memutus rantai kemiskinan di masa mendatang. Beberapa dimensi yang digunakan di dalam penelitian ini antara lain dimensi perumahan, fasilitas, makanan dan nutrisi, pendidikan, perlindungan anak, dan kesehatan. Data yang digunakan adalah data Susenas 2017 dan beberapa data publikasi BPS. Hasil penelitian menunjukkan bahwa 28,63 persen anak di Indonesia miskin multidimensi dengan rata-rata deprivasi yang dialami adalah 40,70 persen dari 13 indikator pembentuk IKM Anak yang digunakan. Dimensi yang paling berkontribusi terhadap kemiskinan anak di Indonesia adalah dimensi pendidikan. Provinsi Papua, NTT, Maluku, dan beberapa provinsi di daerah timur Indonesia memiliki IKM Anak dan persentase penduduk miskin yang tinggi sehingga perlu menjadi prioritas utama dalam upaya pengentasan kemiskinan yang berkelanjutan.
\end{abstract}

Kata kunci: kemiskinan anak, indeks kemiskinan multidimensi, IKM anak, Alkire-Foster

\begin{abstract}
Poverty measurement that only focuses on monetary aspect has long been criticized. Poverty is a multidimensional phenomenon, so poverty measurement should be done in a multidimensional manner, especially child poverty. Child poverty measure in Indonesia usually drawn from the household poverty where the child lives. That is, a child who lives in a non poor household is considered to be not poor either. In reality, children have different needs from adults and the distribution of income within a household is not always equal for all of the family members. This research was conducted to measure child poverty in Indonesia in a multidimensional manner by forming a Multidimensional Poverty Index (MPI) for children, which later on is called Child MPI, based on the Alkire-Foster method. The analysis uses National Social and Economic Survey (Susenas) of 2017 and some other data from Indonesian Statistic Central Bureau (BPS) publications. The result shows that 28,63 percent of children in Indonesia are multi-dimensionally poor with the average deprivation experienced are 40,70 percent of the 13 indicators forming the index. It also shows that the dimension that contributes the most to the child poverty is education. Papua, Nusa Tenggara Timur, Maluku, and other provinces on east side of Indonesia are provinces with the highest Child MPI and monetary poverty so they need to be prioritized in term of sustainable poverty alleviation.
\end{abstract}

Keywords: child poverty, multidimensional poverty index, child MPI, Alkire-Foster

\section{PENDAHULUAN}

Kemiskinan merupakan masalah berkelanjutan yang hingga saat ini masih menjadi fokus utama pembangunan di setiap negara. Upaya pengentasan kemiskinan secara global telah menjadi suatu 
komitmen dan disepakati oleh setiap negara di seluruh dunia dalam Sustainable Development Goals (SDGs). Tinggi rendahnya tingkat kemiskinan di suatu wilayah seringkali digunakan sebagai ukuran kesejahteraan dan sekaligus merefleksikan keberhasilan pembangunan di wilayah tersebut.

Menurut BPS, kemiskinan dipandang sebagai ketidakmampuan dari sisi moneter untuk memenuhi kebutuhan dasar makanan dan bukan makanan yang diukur dari sisi pengeluaran. Pengukuran kemiskinan melalui pendekatan moneter merupakan metode yang paling umum digunakan hingga saat ini. Namun, Sen (1981) memberikan kritik terhadap pendekatan tersebut. Menurutnya, pendekatan tersebut hanya mampu memotret sebagian kecil dari persoalan kemiskinan. Akibatnya, kebijakan pengentasan kemiskinan yang dibuat menjadi tidak tepat dan kurang efektif.

Menurut UNICEF (2016), pada tahun 2013 tercatat sebanyak 767 juta penduduk dunia masih hidup dalam kemiskinan ekstrem. Dari jumlah tersebut, ada sebanyak 385 juta atau 50,2 persen penduduk miskin tersebut masih berada pada usia anak-anak (0-17 tahun). Lebih jauh lagi, sebesar 19,5 persen anak-anak di negara berkembang hidup dalam kemiskinan ekstrem.

UNICEF (2005) mendefinisikan kemiskinan anak sebagai situasi deprivasi yang dialami oleh anakanak dari segi sumber daya materi, spiritual, dan emosional yang dibutuhkan untuk bertahan hidup, berkembang, dan maju yang menimbulkan keterbatasan dalam menikmati hak-hak yang dimilikinya dan mencapai potensi penuh dalam berpartisipasi sebagai anggota masyarakat. Kemiskinan anak dapat memberikan dampak yang merugikan dan sulit untuk diperbaiki yang disebabkan oleh kerentanan akibat faktor usia dan ketergantungannya terhadap orang dewasa. Anak-anak yang tumbuh dalam kemiskinan cenderung memiliki kualitas kesehatan dan pendidikan yang rendah, baik dalam jangka pendek maupun jangka panjang (UNICEF, 2012).

Menurut data yang dikeluarkan oleh UNICEF dan Kementerian PPN/Bappenas (2017), terdapat 8,7 persen atau 7,3 juta anak-anak di Indonesia hidup dalam rumah tangga miskin ekstrem ( $<$ US $\$ 1,90$ per hari) pada tahun 2015. Sementara itu, jika menggunakan garis kemiskinan nasional, terdapat 13,7 persen atau sekitar 11,5 juta anak-anak di Indonesia hidup dalam rumah tangga miskin. Anak-anak yang mengalami deprivasi dalam proses tumbuh kembangnya akan berpeluang besar menjadi penduduk dewasa yang tidak produktif, sehingga akan sulit untuk keluar dari jebakan kemiskinan. Oleh karena itu, upaya pengentasan kemiskinan dimulai pada anak-anak penting untuk dilakukan karena investasi pada anak-anak merupakan sesuatu yang penting dalam rangka mencapai tujuan pembangunan manusia yang berkelanjutan.

Pemerintah Indonesia telah membuat berbagai program untuk mengentaskan kemiskinan, termasuk kemiskinan anak. Akan tetapi, indikator yang digunakan belum dapat mewakili kondisi kemiskinan anak secara spesifik karena masih menggunakan ukuran kemiskinan rumah tangga. Padahal, dalam kenyataannya karakteristik kemiskinan anak berbeda dengan kemiskinan rumah tangga. Hal tersebut karena distribusi ekonomi untuk masing-masing ART dalam rumah tangga tidaklah sama. Menurut Milliano dan Handa (2014), anak-anak memiliki kebutuhan dasar yang berbeda dengan orang dewasa, tetapi distribusi sumber daya di dalam rumah tangga terkadang tidak merata dan anakanak lebih cenderung mendapatkan akses yang kurang terhadap sumber daya tersebut dibandingkan dengan orang dewasa. Dengan demikian, dibutuhkan suatu metode yang lebih spesifik untuk menganalisis kondisi kemiskinan pada anak-anak.

Salah satu pendekatan yang dikenalkan oleh UNICEF (2012) untuk mengukur tingkat kemiskinan anak yaitu Multiple Overlapping Deprivation Analysis (MODA). MODA dibangun berdasarkan pendekatan Bristol dan Multidimensional Poverty Index (MPI) dengan dasar metode Alkire-Foster (AF). MODA merupakan suatu pendekatan komprehensif yang digunakan untuk menganalisis aspek multidimensional dari kemiskinan anak. Pendekatan ini menekankan bahwa kesejahteraan anak terdiri dari berbagai aspek yang tidak dapat dipisahkan satu dengan yang lain sehingga analisis terhadap deprivasi anak harus menempatkan aspek-aspek tersebut secara simultan.

Berdasarkan permasalahan yang telah dijelaskan sebelumnya, perlu dilakukan penelitian mengenai indikator srategis sebagai alat ukur untuk menganalisis kemiskinan anak di Indonesia. Pembentukan IKM Anak perlu disusun dengan memperhitungkan berbagai dimensi, antara lain dimensi perumahan, fasilitas, makanan dan nutrisi, pendidikan, perlindungan anak, dan kesehatan. Dengan demikian, pengentasan kemiskinan dapat diupayakan lebih tepat sasaran terutama pada masalah kemiskinan anak di Indonesia untuk memperkecil potensi kemiskinan di masa yang akan datang. 


\section{METODE}

Jenis data yang digunakan dalam penelitian ini adalah data sekunder berupa raw data hasil Survei Sosial Ekonomi Nasional (Susenas) Maret 2017 dan beberapa data publikasi BPS seperti data Indeks Pembangunan Manusia (IPM) dan data persentase penduduk miskin bulan Maret tahun 2017. Jumlah sampel yang tercakup ke dalam penelitian ini adalah 351.637 penduduk usia 0-17 tahun yang tersebar di seluruh provinsi di Indonesia.

Metode analisis yang digunakan dalam penelitian ini yaitu analisis perhitungan Indeks Kemiskinan Multidimensi (IKM) Anak menggunakan Multiple Overlapping Deprivation Analysis (MODA), analisis validitas IKM Anak menggunakan korelasi rank Spearman, dan analisis penentuan wilayah proritas pengentasan kemiskinan berkelanjutan menggunakan klasifikasi kuadran yang terbentuk dari scatter plot antara persentase penduduk miskin dan IKM Anak.

\section{Penghitungan Indeks Kemsikinan Multidimensi (IKM) Anak}

Tahapan dalam penghitungan IKM Anak menggunakan metode Alkire-Foster meliputi tahap identifikasi (identification) untuk menentukan status kemiskinan unit analisis, dan tahap agregasi (aggregation) untuk menghitung nilai IKM.

Tahap Identifikasi:

1. Pemilihan unit analisis

2. Penentuan dimensi dan indikator

Tabel 1. Dimensi dan indikator pembentuk IKM Anak.

\begin{tabular}{ccc}
\hline No. & Dimensi & Indikator \\
\hline 1. & Perumahan & $\begin{array}{c}\text { Jenis lantai }(0-17 \text { tahun }) \\
\text { Luas lantai per kapita }(0-17 \text { tahun })\end{array}$ \\
\hline 2. & Fasilitas & $\begin{array}{c}\text { Air minum bersih }(0-17 \text { tahun }) \\
\text { Sanitasi layak }(0-17 \text { tahun }) \\
\text { Bahan bakar utama memasak }(0-17 \text { tahun })\end{array}$ \\
\hline 3. & Makanan dan Nutrisi & $\begin{array}{c}\text { Konsumsi kalori }(0-17 \text { tahun }) \\
\text { Pemberian ASI (0-23 bulan) }\end{array}$ \\
\hline 4. & Pendidikan & Partisipasi sekolah sesuai umur $(7-17$ tahun $)$ \\
\hline 5. & Perlindungan Anak & $\begin{array}{c}\text { Kepemilikan akta kelahiran }(0-17 \text { tahun }) \\
\text { Pernikahan usia anak }(10-17 \text { tahun }) \\
\text { Partisipasi pekerja anak (10-17 tahun) }\end{array}$ \\
\hline 6. & Kesehatan & $\begin{array}{c}\text { Kepemilikan jaminan kesehatan } \\
\text { Imunisasi lengkap (12-59 bulan) }\end{array}$ \\
\hline
\end{tabular}

Sumber: UNICEF dan Badan Pusat Statistik

3. Penentuan cut off deprivasi setiap indikator

4. Penentuan penimbang indikator

5. Penghitungan skor deprivasi untuk setiap unit analisis

$c_{i}=w_{1} g_{i 1}^{0}+w_{2} g_{i 2}^{0}+\cdots+w_{13} g_{i 13}^{0}=\sum_{j=1}^{13} w_{j} g_{i j}^{0}$

Keterangan:

$c_{i}=$ Skor deprivasi individu ke-i

$g_{i j}^{0}=$ Status terdeprivasi individu ke-i pada indikator ke-j $\left(g_{i j}^{0}=1\right.$ jika $x_{i j}<z_{j}$ dan

$g_{i j}^{0}=0$ jika $x_{i j} \geq z_{j}$ )

$w_{j}=$ Penimbang indikator ke-j dengan $\sum_{j=1}^{13} w_{j}=1$

6. Penentuan cut off kemiskinan untuk menentukan status kemiskinan unit analisis, yaitu $k=\frac{1}{3}$

Tahap Agregasi:

7. Penghitungan IKM Anak 
8. Penghitungan IKM Anak dilakukan dengan menggunakan formula berikut:

$$
\begin{aligned}
& I K M=H \times A \\
& H=\frac{q}{n} \cdots \cdots \cdots \\
& A=\frac{\sum_{i=1}^{n} c_{i}(k)}{q} .
\end{aligned}
$$

Keterangan:

IKM = Indeks Kemiskinan Multidimensi

$\mathrm{H}=$ Headcount ratio

A $\quad=$ Intensitas kemiskinan

$q \quad=$ Jumlah individu yang dikategorikan miskin multidimensi

$c_{i}(k)=$ Skor deprivasi dari individu miskin multidimensi ke-i

\section{Penentuan Penimbang Terbaik berdasarkan Uji Robustness}

Penentuan penimbang terbaik dari beberapa alternatif penimbang indikator dilakukan dengan melihat kekokohan (robustness) atau ketahanan peringkat IKM Anak terhadap perubahan penimbang yang diberikan. Hal tersebut mengacu pada uji robustness yang telah dilakukan oleh Alkire (2010), yaitu dengan melihat ketahanan peringkat IKM terhadap perubahan penimbang dimensi atau indikator.

Menurut Decanq dan Lugo (2008), pemberian penimbang pada indikator atau dimensi dapat dilakukan dengan beberapa metode, antara lain:

a. Equal Weights: pemberian bobot yang sama besar pada setiap dimensi atau indikator.

b. Data-driven Weighting Schemes

Besarnya penimbang per indikator atau dimensi dapat diperoleh berdasarkan karakteristik data yang tersedia. Adapun beberapa pendekatan yang dapat dilakukan yaitu Frequency-based Weights, Principal Component Analysis (PCA), dan Factor Analysis (FA). Oleh karena jenis data dari indikator yang digunakan bersifat dikotomi, maka dalam penghitungan penimbang dengan pendekatan PCA maupun FA digunakan matriks korelasi tetrachoric.

Penentuan penimbang terbaik berdasarkan uji robustness dilakukan dengan melihat nilai korelasi rank Spearman. Semakin tinggi korelasi yang dihasilkan, semakin kokoh (robust) indeks yang dihasilkan terhadap perubahan parameter yang terjadi. Adapun formula penghitungan korelasi rank Spearman adalah sebagai berikut:

$\frac{6 \sum_{i=1}^{n} d_{i}^{2}}{n\left(n^{2}-1\right)}$

Keterangan:

$r_{S}=$ Korelasi rank Spearman

$r_{a}=$ Peringkat kombinasi IKM a

$r_{b}=$ Peringkat kombinasi IKM b

$d_{i}=r_{a}-r_{b}$

$n=$ Jumlah sampel

$i=1,2, \ldots, n$

\section{Uji Validitas IKM Anak}

Validitas dapat diartikan sebagai tingkat kebaikan ukuran yang telah dihasilkan dalam mengukur karakteristik yang akan diukur. Dalam hal ini, ukuran IKM Anak dianggap valid apabila dapat dibandingkan dengan suatu ukuran referensi. Salah satu cara yang dapat dilakukan untuk menguji validitas adalah melalui uji korelasi (Karras, 1997). Untuk itu, uji validitas di dalam penelitian ini dilakukan dengan analisis korelasi rank antara IKM Anak dan IPM yang dihasilkan oleh BPS.

\section{Kontribusi Dimensi dan Indikator}

Kontribusi dimensi dan indikator menunjukkan seberapa besar peran dimensi dan indikator dalam menentukan seorang individu dikategorikan sebagai individu miskin multidimensi. Penghitungan kontribusi dimensi dan indikator melibatkan censored headcount ratio $\left(h_{i}(k)\right)$, yaitu proporsi individu 
yang teridentifikasi sebagai individu miskin multidimensi $\left(c_{i} \geq k\right)$ dan sekaligus terdeprivasi pada dimensi atau indikator yang akan dihitung kontribusinya.

$\emptyset_{i}(k)=w_{i} \frac{h_{i}(k)}{M_{0}}$

$M_{0}=\sum_{i=1}^{13} w_{i} h_{i}(k)$

Keterangan:

$\emptyset_{i}(k)=$ Persentase kontribusi dari indikator $i$ pada cut off $k$

$w_{i} \quad=$ Penimbang indikator $i$

$h_{i}(k)=$ Censored headcount ratio

\section{HASIL DAN PEMBAHASAN}

\section{Gambaran Deprivasi Anak pada Multidimensi}

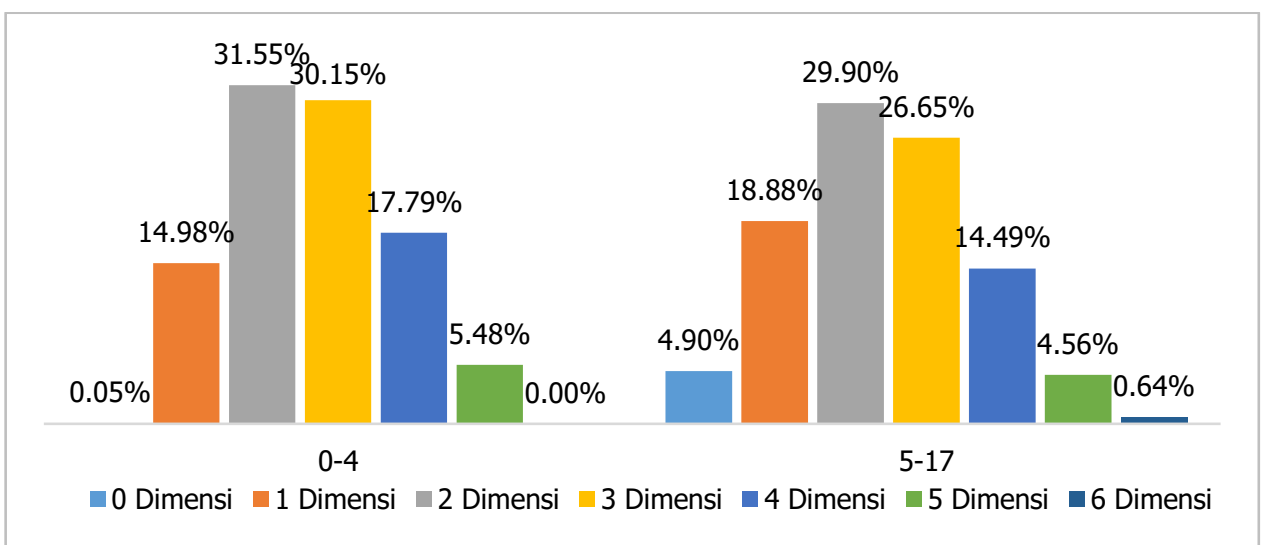

Gambar 1. Persentase anak yang terdeprivasi menurut jumlah dimensi dan kelompok umur.

Berdasarkan Gambar 1 dapat diketahui bahwa mayoritas anak di Indonesia baik pada kelompok umur 0-4 tahun maupun 5-17 tahun mengalami deprivasi pada 2 atau 3 dimensi dan hanya sebagian kecil yang mengalami deprivasi pada 5 atau 6 dimensi. Selain itu, persentase anak usia 0-4 tahun yang tidak terdeprivasi lebih kecil dibandingkan dengan anak usia 5-17 tahun, yaitu 0,05 persen berbanding 4,90 persen.

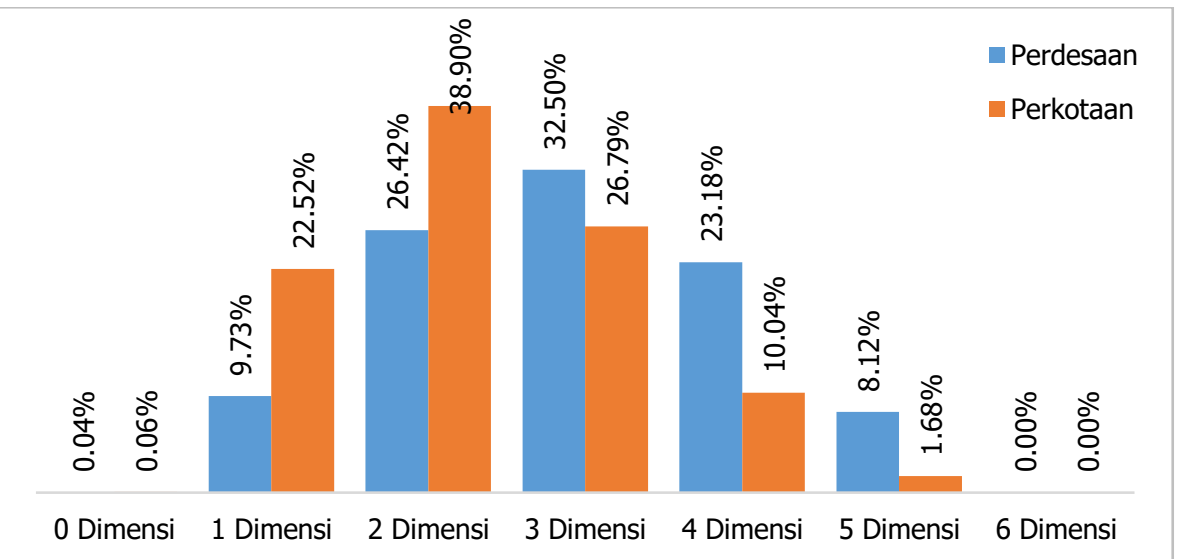

Gambar 2. Persentase anak usia 0-4 tahun yang terdeprivasi menurut jumlah dimensi dan tipe daerah.

Berdasarkan Gambar 2 dapat diketahui bahwa anak usia 0-4 tahun yang tinggal di daerah perdesaan sebagian besar mengalami deprivasi pada 3 dimensi, yaitu sebesar 32,50 persen. Sementara itu, anak yang tinggal di daerah perkotaan sebagian besar mengalami deprivasi pada 2 dimensi, yaitu sebesar 38,90 persen. Jika dibandingkan, anak yang tinggal di perdesaan lebih terdeprivasi pada jumlah dimensi yang lebih banyak dibandingkan dengan anak yang tinggal di perkotaan. Hal tersebut terlihat pada persentase terdeprivasi anak perdesaan yang lebih tinggi dibandingkan dengan anak di perkotaan seiring dengan bertambahnya jumlah dimensi yang terdeprivasi. 


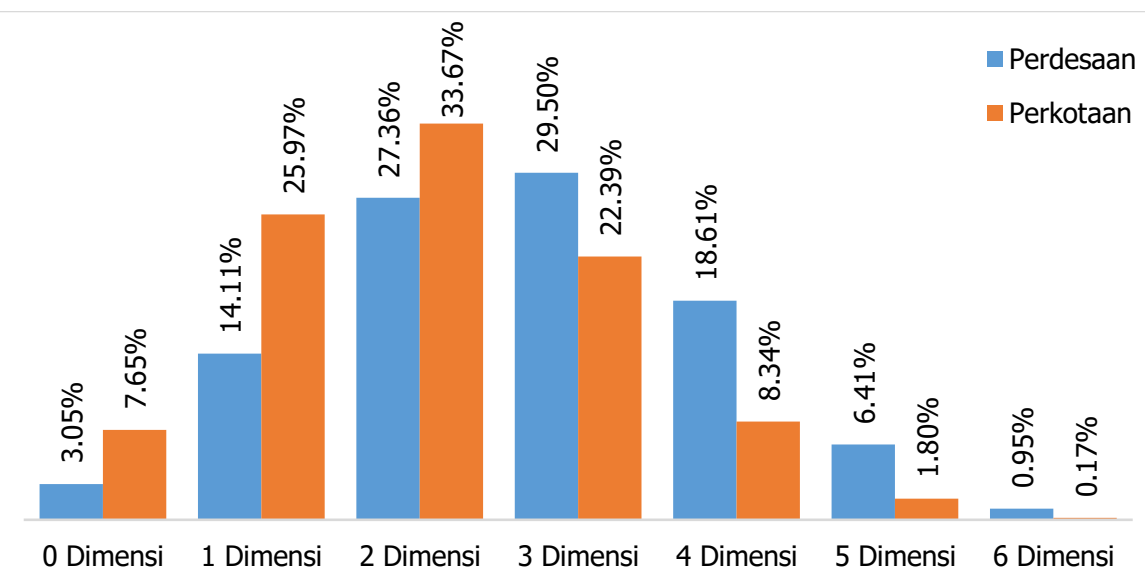

Gambar 3. Persentase anak usia 5-17 tahun yang terdeprivasi menurut jumlah dimensi dan tipe daerah.

Berdasarkan Gambar 3, anak yang tinggal di daerah perdesaan paling banyak mengalami deprivasi pada 3 dimensi, yaitu sebesar 29,50 persen. Sementara itu, anak yang tinggal di daerah perkotaan paling banyak mengalami deprivasi pada 2 dimensi, yaitu sebesar 33,67 persen. Sama halnya dengan anak usia 0-4 tahun, anak usia 5-17 tahun yang tinggal di perdesaan lebih terdeprivasi pada jumlah dimensi yang lebih banyak dibandingkan dengan anak yang tinggal di perkotaan. Hal tersebut terlihat pada persentase terdeprivasi anak perdesaan yang lebih tinggi dibandingkan dengan anak di perdesaan seiring dengan bertambahnya jumlah dimensi yang terdeprivasi.

\section{Indeks Kemiskinan Multidimensi (IKM) Anak}

Penentuan Penimbang Terbaik Berdasarkan Uji Robustness

Berikut ini adalah hasil korelasi rank Spearman IKM Anak berdasarkan kombinasi penimbang dimensi/indikator yang diajukan. 
Tabel 2. Nilai korelasi rank Spearman IKM Anak provinsi di Indonesia antarkombinasi penimbang dimensi.

\begin{tabular}{ccccccccc}
\hline & IKM A & IKM B & IKM C & IKM D & IKM E & IKM F & IKM G & IKM H \\
\hline IKM A & 1,000 & $0,979 *$ & $0,797^{*}$ & $0,870^{*}$ & $0,915^{*}$ & $0,932 *$ & $0,663^{*}$ & $0,758^{*}$ \\
IKM B & $0,979 *$ & 1,000 & $0,774^{*}$ & $0,881^{*}$ & $0,882^{*}$ & $0,940^{*}$ & $0,672^{*}$ & $0,755^{*}$ \\
IKM C & $0,797^{*}$ & $0,774 *$ & 1,000 & $0,499^{*}$ & $0,868^{*}$ & $0,653^{*}$ & 0,217 & $0,363^{*}$ \\
IKM D & $0,870^{*}$ & $0,881^{*}$ & $0,499^{*}$ & 1,000 & $0,723^{*}$ & $0,893^{*}$ & $0,810^{*}$ & $0,863^{*}$ \\
IKM E & $0,915^{*}$ & $0,882^{*}$ & $0,868^{*}$ & $0,723^{*}$ & 1,000 & $0,761^{*}$ & $0,514^{*}$ & $0,625^{*}$ \\
IKM F & $0,932^{*}$ & $0,940^{*}$ & $0,653^{*}$ & $0,893^{*}$ & $0,761^{*}$ & 1,000 & $0,722^{*}$ & $0,780^{*}$ \\
IKM G & $0,663^{*}$ & $0,672^{*}$ & 0,217 & $0,810^{*}$ & $0,514^{*}$ & $0,722^{*}$ & 1,000 & $0,958^{*}$ \\
IKM H & $0,758^{*}$ & $0,755^{*}$ & $0,363^{*}$ & $0,863^{*}$ & $0,625^{*}$ & $0,780^{*}$ & $0,958^{*}$ & 1,000 \\
\hline Rata-rata & 0,864 & 0,860 & 0,646 & 0,817 & 0,786 & 0,835 & 0,695 & 0,763 \\
\hline
\end{tabular}

Sumber: Susenas 2017, diolah

*) Korelasi signifikan pada tingkat signifikansi 0,05 (dua arah)

Keterangan:
A, B: Equal weights
C, D, E, F: Frequency-based weights
G: Principal Component Analysis (PCA)
$\mathrm{H}$ : Factor Analysis (FA)

Berdasarkan Tabel 2, dapat diketahui bahwa kombinasi penimbang dengan rata-rata korelasi terbesar adalah kombinasi penimbang $\mathrm{A}$ atau equal weights, yaitu kombinasi penimbang dengan pemberian bobot yang sama untuk setiap dimensi pembentuk IKM Anak. Penimbang tersebut selanjutnya dipilih sebagai penimbang untuk menghitung IKM Anak Indonesia beserta IKM Anak di setiap provinsi di Indonesia.

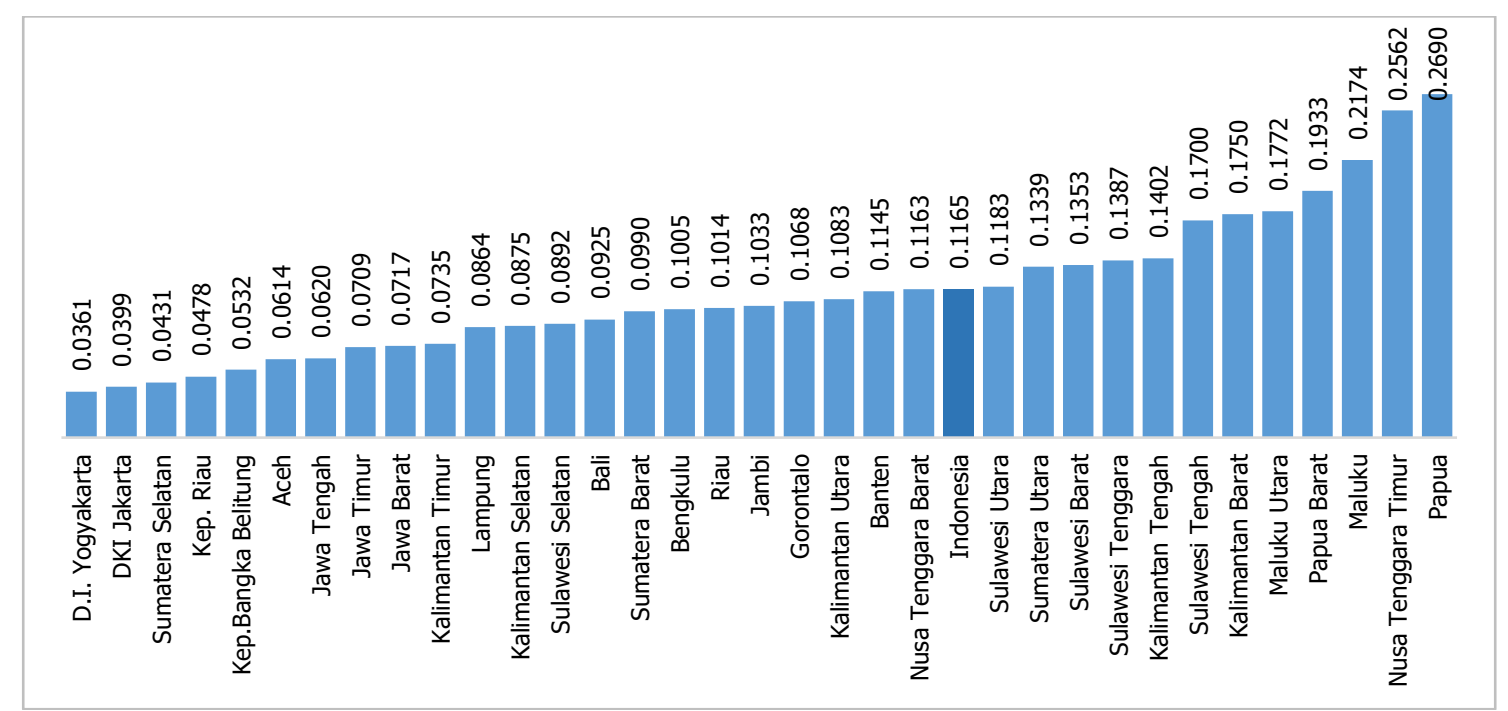

Gambar 4. IKM Anak menurut provinsi di Indonesia.

Berdasarkan Gambar 4, diketahui bahwa besarnya IKM Anak Indonesia adalah 0,1165, dengan headcount ratio sebesar 0,2863 dan intensitas sebesar 0,4070. Artinya, sebanyak 28,63 persen anak di Indonesia miskin secara multidimensi dengan rata-rata deprivasi yang dialami adalah 40,70 persen dari 13 indikator penyusun IKM Anak. Nilai IKM Anak 0,1165 berarti rata-rata deprivasi yang dialami oleh seluruh anak di Indonesia adalah 11,65 persen dari 13 indikator penyusun IKM Anak.

Dari ke-34 provinsi di Indonesia, IKM Anak tertinggi terdapat di Provinsi Papua, yaitu sebesar 0,2690 dengan headcount ratio sebesar 0,6173 dan intensitas sebesar 0,4358. Artinya, 61,73 persen anak di Papua dikategorikan sebagai anak miskin multidimensi dan rata-rata deprivasi yang dialami anak miskin tersebut adalah 43,58 persen dari 13 indikator penyusun IKM Anak. Beberapa provinsi lain dengan nilai IKM Anak tertinggi di antaranya Provinsi NTT, Maluku, dan Papua Barat. 


\section{Uji Validitas IKM Anak dengan Indeks Pembangunan Manusia (IPM)}

Hasil korelasi rank Spearman menunjukkan bahwa ukuran IKM Anak dan IPM memiliki korelasi kuat dan signifikan, yaitu sebesar -0,680. Tanda negatif menunjukkan hubungan antara kemiskinan dan pembangunan. Penyajian perbandingan antara IKM Anak dan IPM dalam bentuk peta tematik dapat dilihat pada Gambar 5.

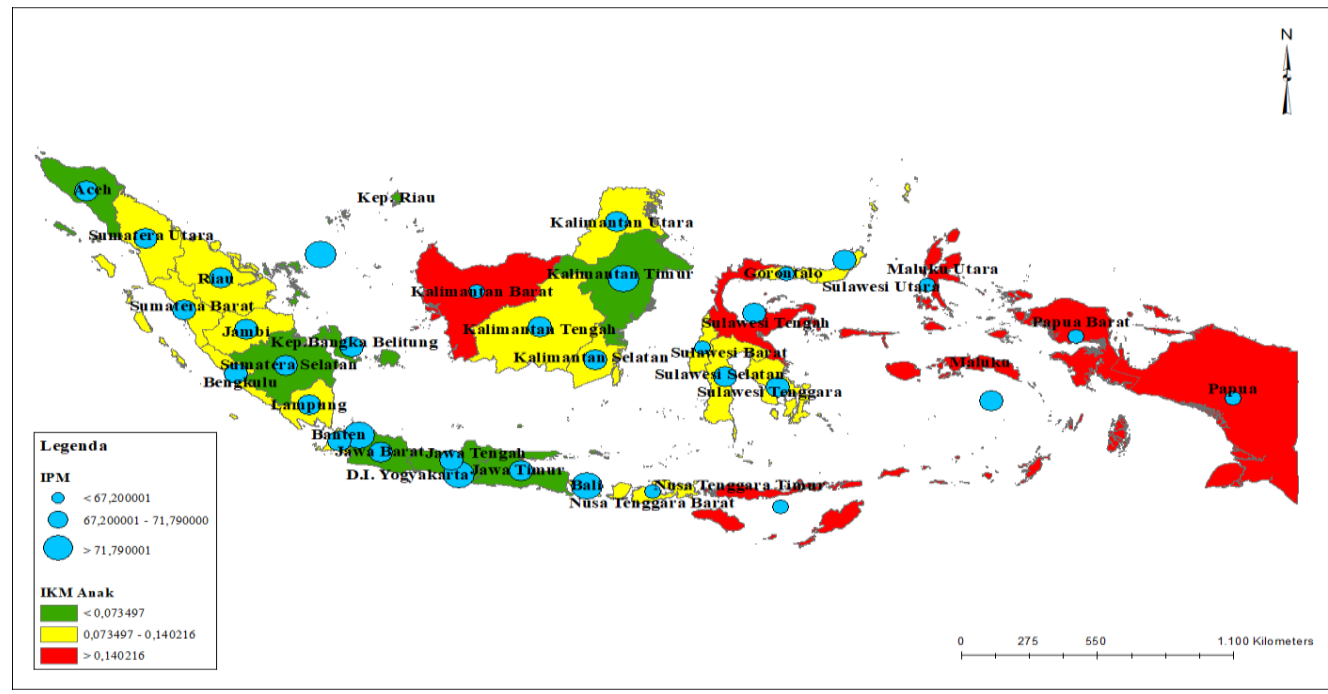

Gambar 5. Peta tematik IKM Anak dan Indeks Pembangunan Manusia (IPM) 2017.

Berdasarkan Gambar 5, dapat dilihat bahwa hasil penghitungan IKM Anak menunjukkan pola yang berkebalikan dengan IPM. Provinsi dengan kategori IKM Anak yang tinggi cenderung memiliki IPM dengan kategori rendah, begitu pula sebaliknya. Dengan demikian, dapat disimpulkan bahwa ukuran IKM Anak yang telah dihasilkan dapat digunakan sebagai indikator alternatif dalam mengukur pembangunan manusia di Indonesia.

\section{Pemanfaatan IKM Anak untuk Pengentasan Kemiskinan Berkelanjutan}

IKM Anak tersebut selanjutnya dimanfaatkan untuk mengetahui peran setiap dimensi dan indikator terhadap kemiskinan anak serta untuk mengetahui wilayah prioritas untuk kebijakan pengentasan kemiskinan berkelanjutan. Untuk mencapai tujuan tersebut, dilakukan penghitungan kontribusi setiap dimensi dan indikator dan pengklasifikasian wilayah provinsi di Indonesia berdasarkan analisis kuadran.

Kontribusi Dimensi dan Indikator terhadap Kemiskinan Anak

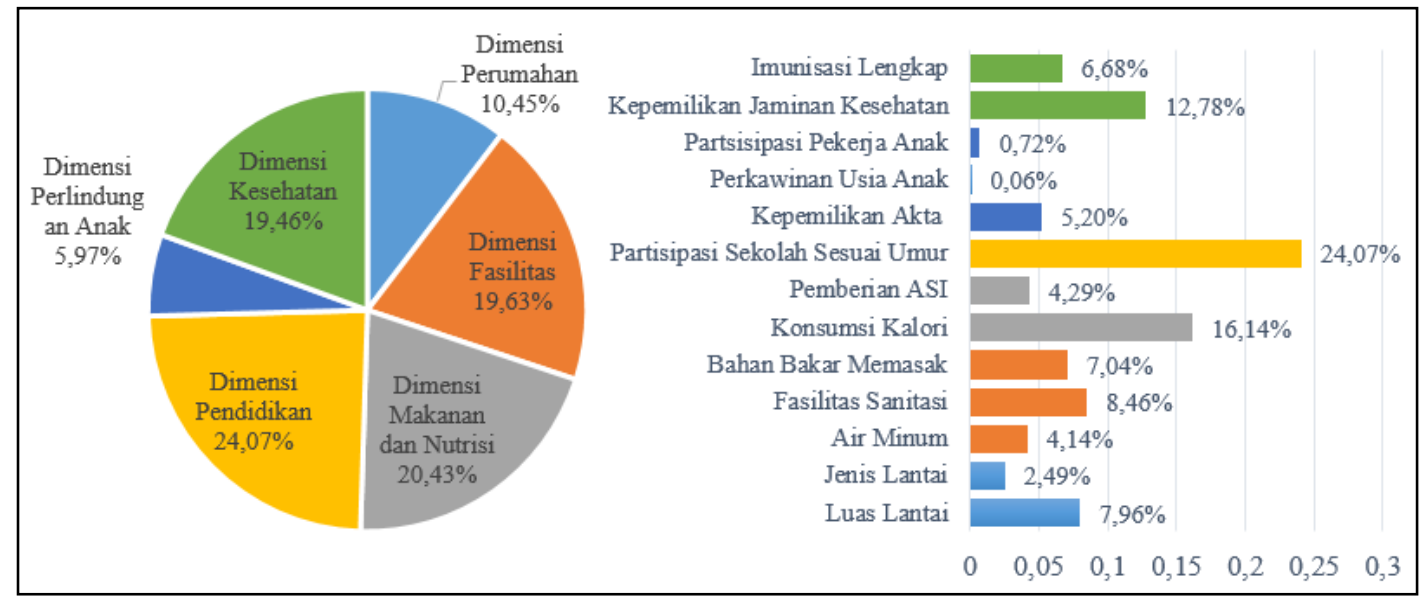

Gambar 6. Kontribusi dimensi dan indikator.

Berdasarkan Gambar 6, dapat diketahui bahwa dimensi dengan persentase kontribusi terbesar adalah dimensi pendidikan yaitu sebesar 24,07 persen, diikuti oleh dimensi makanan dan nutrisi, yaitu 
sebesar 20,43 persen. Sementara itu, dimensi perlindungan anak adalah dimensi dengan persentase kontribusi terkecil, yaitu 5,97 persen. Apabila dilihat menurut indikator dapat diketahui bahwa indikator dengan kontribusi terbesar adalah partisipasi sekolah sesuai umur, yaitu sebesar 24,07 persen. Sedangkan indikator dengan kontribusi terkecil adalah perkawinan usia anak, yaitu sebesar 0,06 persen.

\section{Penentuan Wilayah Prioritas Pengentasan Kemiskinan Berkelanjutan}

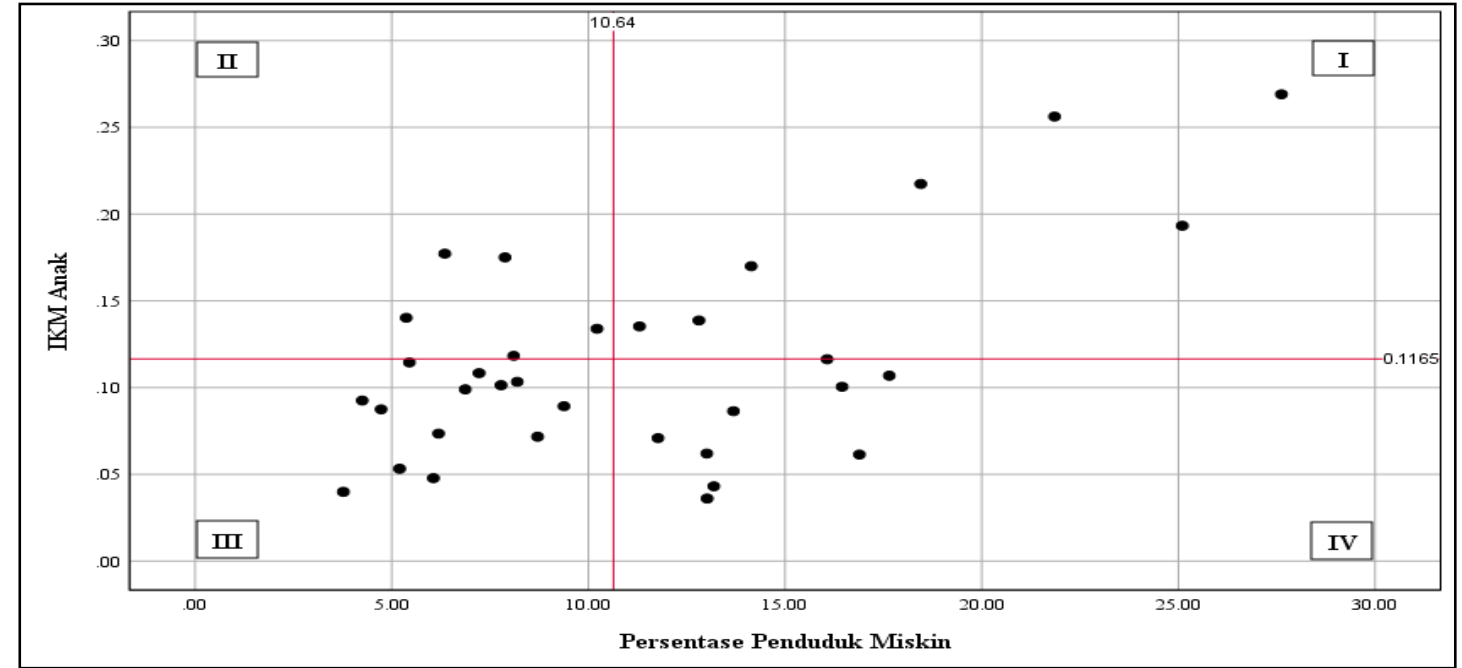

Gambar 7. Klasifikasi kuadran provinsi berdasarkan persentase penduduk miskin dan IKM Anak.

Gambar 7 menunjukkan klasifikasi kuadran dari provinsi di Indonesia berdasarkan persentase penduduk miskin dan IKM Anak. Berdasarkan sebaran titik yang dihasilkan, terlihat bahwa secara umum terdapat hubungan yang positif antara persentase penduduk miskin dan IKM Anak, artinya provinsi dengan persentase penduduk miskin yang tinggi cenderung untuk memiliki IKM Anak yang tinggi, begitu pula sebaliknya. Informasi mengenai provinsi mana saja yang termasuk ke dalam masing-masing kuadran disajikan pada Tabel 3.

Tabel 3. Klasifikasi kuadran provinsi berdasarkan persentase penduduk miskin dan persentase anak miskin multidimensi.

\begin{tabular}{|c|c|c|}
\hline & Kuadran & Provinsi \\
\hline $\mathrm{I}$ & $\begin{array}{l}\text { Provinsi dengan persentase penduduk } \\
\text { miskin di bawah angka nasional tetapi } \\
\text { IKM Anak di atas angka nasional. }\end{array}$ & $\begin{array}{l}\text { Sumatera Utara, Kalimantan Barat, } \\
\text { Kalimantan Tengah, Sulawesi Utara, } \\
\text { Maluku Utara. }\end{array}$ \\
\hline II & $\begin{array}{l}\text { Provinsi dengan persentase penduduk } \\
\text { miskin dan IKM Anak di atas angka } \\
\text { nasional. }\end{array}$ & $\begin{array}{l}\text { Nusa Tenggara Timur, Sulawesi } \\
\text { Tengah, Sulawesi Tenggara, Sulawesi } \\
\text { Barat, Maluku, Papua Barat, Papua. }\end{array}$ \\
\hline III & $\begin{array}{l}\text { Provinsi dengan persentase penduduk } \\
\text { miskin dan IKM Anak di bawah angka } \\
\text { nasional. }\end{array}$ & $\begin{array}{l}\text { Sumatera Barat, Riau, Jambi, Kep. } \\
\text { Bangka Belitung, Kep. Riau, DKI } \\
\text { Jakarta, Jawa Barat, Banten, Bali, } \\
\text { Kalimantan Selatan, Kalimantan Timur, } \\
\text { Kalimantan Utara, Sulawesi Selatan }\end{array}$ \\
\hline IV & $\begin{array}{l}\text { Provinsi dengan persentase penduduk } \\
\text { miskin di atas angka nasional tetapi IKM } \\
\text { Anak di bawah angka nasional. }\end{array}$ & $\begin{array}{l}\text { Aceh, Sumatera Selatan, Bengkulu, } \\
\text { Lampung, Jawa Tengah, D.I. } \\
\text { Yogyakarta, Nusa Tenggara Barat, } \\
\text { Jawa Timur, Gorontalo. }\end{array}$ \\
\hline
\end{tabular}

Berdasarkan informasi pada Tabel 3, dapat disimpulkan bahwa wilayah yang memerlukan prioritas utama adalah provinsi yang berada pada kuadran II. Anak-anak yang berada pada wilayah tersebut memiliki tantangan yang lebih besar untuk dapat keluar dari kemiskinan karena keterbatasan baik dari aspek moneter maupun non moneter. Berbagai program pengentasan kemiskinan seperti Program Keluarga Harapan (PKH) dan beras sejahtera (rastra) yang selama ini dianggap berkontribusi besar 
terhadap penurunan tingkat kemiskinan harus diupayakan agar dapat berjalan dengan lebih efektif. Sementara itu, strategi pengentasan kemiskinan anak dapat dimulai dengan melihat dimensi atau indikator yang paling berkontribusi terhadap kemiskinan anak di wilayah tersebut. Dimensi pendidikan memiliki kontribusi terbesar terhadap kemiskinan di Provinsi, NTT, Selawesi Tengah, Sulawesi Tenggara, Sulawesi Barat, dan Maluku. Sementara itu, dimensi fasilitas memiliki kontribusi terbesar di Provinsi Papua Barat dan Papua.

Wilayah yang perlu menjadi prioritas selanjutnya adalah provinsi yang termasuk ke dalam kuadran I. Berdasarkan hasil pengukuran kontribusi dimensi, diketahui bahwa dimensi yang paling berkontribusi terhadap kemiskinan anak di wilayah yang termasuk ke dalam kuadran I dan II adalah dimensi pendidikan. Sen (1992) menyatakan bahwa pendidikan memiliki kaitan yang kuat dengan kapabilitas individu dan berdampak pada kesejahteraan. Pendidikan yang lebih baik dapat meningkatkan kapabilitas individu dan meningkatkan peluang untuk memutus rantai kemiskinan. De Ferranti et al. (2003) juga menggambarkan pentingnya investasi di bidang pendidikan untuk meningkatkan produktivitas dan pertumbuhan yang berkelanjutan. Untuk itu, pendidikan merupakan dimensi yang penting dan perlu menjadi prioritas pemerintah dalam upaya pengentasan kemiskinan yang berkelanjutan.

Dalam penelitian Roche (2013), disebutkan bahwa kebijakan yang dapat diambil untuk menurunkan kemiskinan anak dapat dilakukan melaui dua pendekatan, yaitu dengan berorientasi pada penurunan insiden kemiskinan/headcount ratio $(\mathrm{H})$ atau pada penurunan intensitas kemiskinan $(\mathrm{A})$. Pengentasan kemiskinan anak yang berorientasi pada penurunan headcount ratio tidak memperhatikan intensitas kemiskinan yang dialami, sehingga kelompok penduduk yang paling miskin (the poorest of the poor) tidak menjadi prioritas. Sementara itu, pendekatan kedua berorientasi pada penurunan intensitas kemiskinan, yaitu dengan lebih memprioritaskan kelompok anak dengan jumlah deprivasi yang paling banyak yang UNICEF sebut sebagai pendekatan equity-focused. Hasil penelitian terdahulu menunjukkan bahwa kedua pendekatan tersebut memberikan dampak yang lebih baik satu dibandingkan dengan yang lain di wilayah yang berbeda. Untuk itu, pada kasus Indonesia perlu dilakukan penelitian lanjutan mengenai pendekatan yang paling tepat untuk digunakan dalam menurunkan tingkat kemiskinan anak dengan melakukan perbandingan antarwaktu terhadap kemiskinan anak di Indonesia sebelum dan setelah diberlakukannya kebijakan.

\section{KESIMPULAN}

Berdasarkan hasil dan pembahasan sebelumnya, maka kesimpulan yang dapat diambil antara lain yang pertama, sebagian besar anak di Indonesia terdeprivasi pada 2 dan 3 dimensi. Kedua, secara umum, anak yang tinggal di daerah perdesaan lebih terdeprivasi pada dimensi yang lebih banyak dibandingkan dengan anak yang tinggal di daerah perkotaan. Ketiga, sebesar 28,63 persen anak di Indonesia miskin multidimensi dengan rata-rata deprivasi yang dialami adalah 40,70 persen dari 13 indikator pembentuk IKM Anak. Keempat, wilayah dengan IKM Anak tertinggi di Indonesia, antara lain Provinsi Papua, Nusa Tenggara Timur, Maluku, dan Papua Barat. Kelima, IKM Anak yang telah dihasilkan dapat menjadi indikator alternatif dalam mengukur pembangunan manusia di Indonesia. Keenam, dimensi pendidikan adalah dimensi dengan kontribusi paling besar terhadap kemiskinan anak di Indonesia, yaitu sebesar 24,07 persen, sehingga dimensi pendidikan perlu menjadi prioritas dalam upaya pengentasan kemiskinan yang berkelanjutan. Ketujuh, wilayah yang perlu menjadi prioritas utama dalam upaya pengentasan kemiskinan berkelanjutan adalah Provinsi Papua, Papua Barat, Maluku, Sulawesi Barat, Sulawesi Tenggara, Sulawesi Tengah, dan NTT. 


\section{UCAPAN TERIMA KASIH}

Terima kasih penulis ucapkan kepada semua pihak yang telah membantu penulis dalam menyelesaikan penelitian ini, terutama kepada Ibu Ika Yuni Wulansari, S.S.T., M.Stat., selaku dosen pembimbing dan kepada Saudara Arif yang telah memberikan bantuan dan dukungan selama proses penelitian berlangsung.

\section{DAFTAR PUSTAKA}

Alkire, S. Santos, M.E. (2013). A Multidimensional Approach: Poverty Measurement and Beyond. Social Indicators Research, 112(2): 239-257.

Alkire, S. Santos, M.E. (2013). Measuring Acute Poverty in the Developing World: Robustness and Scope of the Multidimensional Poverty Index. OPHI Working Paper No. 59.

Alkire, S. Foster, J. E. (2015). Multidimensional Poverty Measurement and Analysis: Chapter 5 - The Alkire-Foster Counting Methodology. OPHI Working Paper No.86.

Bellinger, W. K. (2007). The Economics Analysis of Public Policy. Routledge: Oxon.

Bourguignon, Francois. Cakravarty, S. R. (2003). The Measurement of Multidimensional Poverty. Journal of Economic Inequality (25). Netherland.

de Millano, M. Handa, S. (2014). Child Poverty and Deprivation in Mali. Office of Research Working Paper, WP2014-20. UNICEF.

Decanq, Koen. Lugo, Maria Ana. (2009). Setting Weights in Multidimensional Indices of Well-being and Deprivation. OPHI Working Paper No. 18. University of Oxford.

Gordon, David et al. (2003). Child Poverty in The Developing World. Policy Press: Bristol.

Karras, David J. (1997). Statistical Methodology: II. Reliability and Validity Assessment in Study Design, Part A. Academic Emergency Medicine Vol.4/No.1.

Sen, Amartya. (1981). Poverty and Famines: An Essay on Entitlement and Deprivation. Oxford: Oxford University Press.

Roche, M.J. (2013). Monitoring Progress in Child Poverty Reduction: Methodological Insights and Illustration to the Case Study of Bangladesh. OPHI Working Paper No.57. University of Oxford.

UNICEF. (2005). The State of The World's Children, Childhood under Threat. UNICEF.

UNICEF. (2016). Ending Extreme Poverty: a Focus on Children. UNICEF.

UNICEF. (2017). SDG Baseline Report on Children in Indonesia. UNICEF. 